\title{
WORLDWIDE DISEASE - HAEMORRHOIDS. HOW MUCH DO WE KNOW?
}

\author{
Inese Fišere ${ }^{1, \#}$, Valērija Groma ${ }^{3}$, Niks Ričards Goldiṇš ${ }^{3}$, Andris Gardovskis ${ }^{1,2}$, \\ Jānis Gardovskis ${ }^{1,2}$

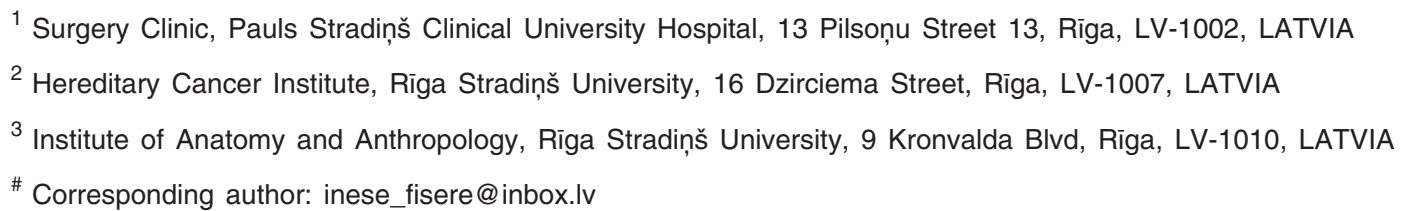

Contributed by Jānis Gardovskis

\begin{abstract}
Haemorrhoids are highly vascular cushions of connective tissue in the anal canal, which are normal structures of the human body. Haemorrhoidal disease in clinical practice means that there is an abnormal enlargement of the anal cushions when these transform into "anal nodules", bleed and/or prolapse. Haemorrhoidal disease is very common. Despite numerous studies undertaken and knowledge accumulated on the aetiology and pathogenesis of haemorrhoidal disease in the last decade, the specific mechanisms responsible for the development of the disease are not thoroughly understood. The pathophysiology is most likely multifactorial and complex, manifested by muscle weakness, intrarectal prolapse, changes in vascular pressure and flow in blood vessels, malformations, sphincter damage and failure, venostasis, inflammatory reactions, endothelin and collagen abnormalities, matrix metalloproteinases activity, etc. Currently, treatment guidelines for the haemorrhoidal disease are based on Goligher's classification. The classification of haemorrhoidal disease should be submitted to revision by including aetiological factors, the dynamism of prolapse, symptomatology, enteropathogenesis, and gender characteristics. The present review is focused on recent data gained by exploring the anatomy, pathophysiology, classification, theories explaining the development of haemorrhoids, as well as aetiological invasive and surgical treatment modalities.
\end{abstract}

Key words: anal canal, anatomy, pathophysiology, classification of haemorrhoidal disease, invasive treatment.

\section{INTRODUCTION}

Haemorrhoidal disease is defined as a symptomatic enlargement and distal displacement of normal anal cushions. Haemorrhoids were described already in the pre-Christian era (Nasseri et al., 2015). There is no data on the actual incidence of haemorrhoidal disease, and various studies report a prevalence between $4 \%$ and $40 \%$ (Lohsiriwat et al., 2015). There were slightly less than 1000 patients diagnosed with the haemorrhoidal disease in Pauls Stradiňs Clinical University Hospital in 2019, and surgical treatment for stage III and IV was applied in 267 cases. The disease usually affects patients aging 45-65 years, but nowadays, younger patients are diagnosed with haemorrhoids. Numer- ous contradicting factors have been considered as risk factors for the development of the disease. The common risk factors are considered to be pregnancy, constipation/chronic diarrhea, internal rectal prolapse, aging, obesity, depressive mood, prolonged straining, low fiber diet, spicy food, alcohol intake, chronic cough, strenuous exercises, weight lifting, long-standing, family history, etc. Nevertheless, research has continued and shown that gravidity and overweight do not appear to be associated with haemorrhoidal disease, and that high grain fiber intake and sedentary behavior reduces the risk for the development of haemorrhoids (Perry et al., 2015). In women, the main risk factors are pregnancy, number of births, constipation, chronic venous disease, and increased body mass index, in men - 
constipation, increased body mass index, and chronic venous disease (Godeberge et al., 2020). Furthermore, enlarged prostate, urethral stricture, ovarian tumour, rectosigmoid carcinoma, and ascites have been extensively studied due to risk for haemorrhoids (Lohsiriwat, 2018). Various theories based on pathophysiological changes observed in haemorrhoidal disease, including abnormal dilatation of veins of internal haemorrhoidal plexus, dilatation of arteriovenous anastomoses, and prolapse of the cushion have been proposed (Lohsiriwat, 2018). Association between haemorrhoids and the subsequent risk of development of coronary heart disease has been shown. Recently, it was shown that patients with haemorrhoids had a 1.27-fold higher risk of the development of coronary heart disease when compared with patients without haemorrhoids (Chang et al., 2017). Furthermore, about $25 \%$ of patients with haemorrhoids had an increased risk of development of peripheral arteriopathy and atherosclerosis (Hu et al., 2017). Currently, there is no conclusive evidence of hereditary predisposition. Various environmental and endogenous factors may act together to lead to the development of haemorrhoidal disease. Despite numerous studies undertaken to explore epidemiology, risk factors contributing to the development of the disease, and methods of treatment, the pathogenetic mechanisms and, therefore, the clinical management of the haemorrhoidal disease, remain not completely understood.

\section{ANATOMY OF THE ANAL CANAL}

The anal canal is the end of the colon, located within the anal triangle of the perineum, between the right and left ishioanal fossae (Guo et al., 2007; Luis et al., 2018). The anal canal is about $2.5-4 \mathrm{~cm}$ in length and encircled by the anal sphincter complex (Fig. 1). An internal anal sphincter surrounds the upper $2 / 3$ of the anal canal, formed by a thickening of involuntary circular smooth muscle, whereas an external anal sphincter, which is a voluntary muscle, surrounds the lower $2 / 3$ of the anal canal, overlapping the internal sphincter (Hassan et al., 2016; Stewart et al., 2018; Nakashima et al., 2020). The subepithelial space of the anal canal is uneven. There are prominences of anal mucosa, known as "anal cushions", formed by loose connective tissue, smooth muscle, arteriole, venule, and anorectal vascular plexus - haemorrhoidal plexus (Aigener et al., 2009; Lohsiriwat, 2018). The functions of anal cushions are to maintain anal continence and to allow greater anal distension during defecation. They fill the gaps within the sphincter ring (Margetis, 2019). When defecating, external anal sphincter muscles relax and allow glissade anal cushions. The anal cushion is supported by a fibroelastic tissue and smooth muscle. This muscle and the mucosal suspensory ligament or Park's ligament collectively contribute to the formation of Trietz's muscle (Hassan et al., 2016; Zoulamoglou et al., 2017; Lohsiriwat, 2018; Margetis, 2019; Ahmed et al., 2020; Nakashima et al., 2020). The conjoined longitudinal muscle is located inferiorly along the canal, lying between the internal and external anal sphincters (Fig. 1). The muscle splits into bundles, which pierce the internal

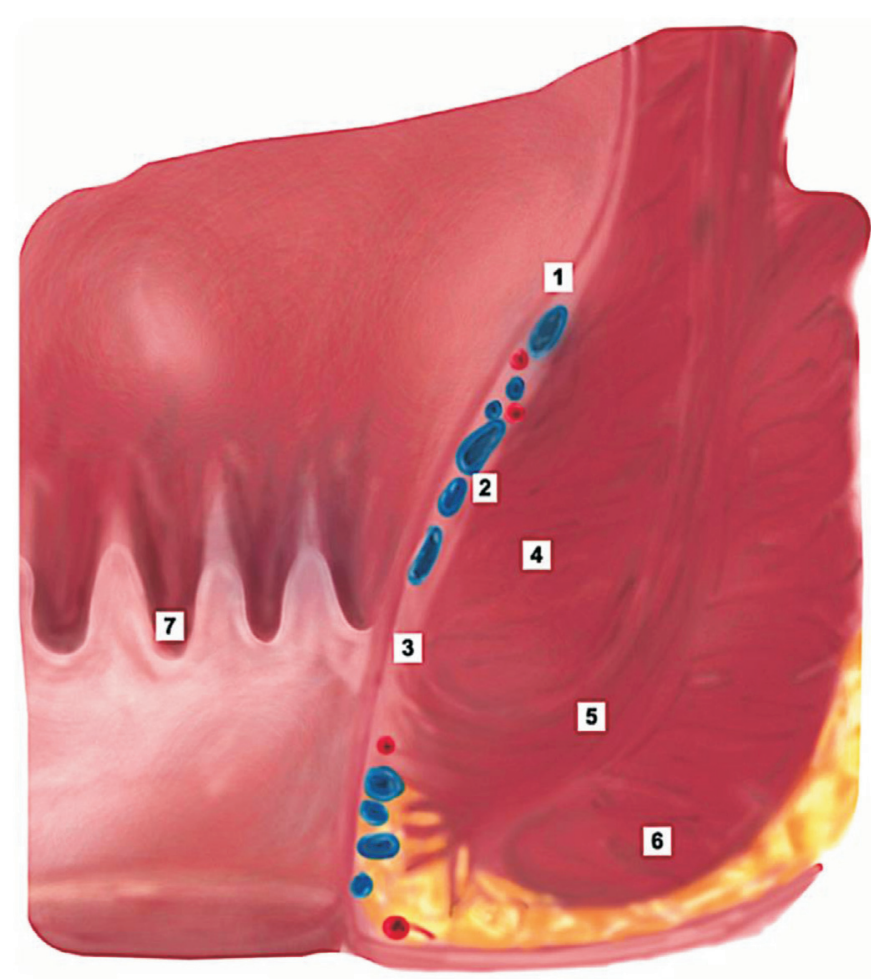

Fig. 1. Anatomy of the anal canal: 1 - muscularis mucosa; 2 - internal haemorrhoidal plexus; 3 - Trietz's muscle; 4 - internal anal sphincter; 5 conjoined longitudinal muscle; 6 - external anal sphincter; 7 - dentate line.

anal sphincter and submucosa to connect with the muscularis mucosa of the canal and support the surrounding vascular plexuses. The muscularis mucosa gradually becomes indistinct (Fig. 1). These anchoring fibromuscular structures contribute to the stability of the vasculature and aid in the prevention of rectal prolapse (Sundel et al., 2019).

Within each anal cushion, there is an anorectal vascular plexus formed by direct arteriovenous communication between the terminal branches of superior, middle, or inferior rectal arteries and their corresponding veins (Erden, 2018; Lohsiriwat, 2018). Within the anorectal vascular plexus, there are several sphincter-like structures formed by a thickened tunica media of venous vessels. The vessels contain 5 up to 15 layers of smooth muscle cells. These facilitate venous drainage by contractions (Fontem et al., 2020). The superior part of the anal canal has the same epithelial lining as the rectum - simple columnar (Luis et al., 2018). The mucosa is organised in longitudinal folds - anal or Morgagni columns (Lohsiriwat, 2018). These are joined at their inferior ends by anal valves, and above them are small pouches that are referred to as anal sinuses containing glands that secrete mucus (Li et al., 2015; Lohsiriwat, 2015). The anal valves collectively form an irregular circle - pectinate line or dentate line (Margetis, 2019). The dentate line divides the anal canal into two parts displaying differences both in the developmental peculiarities and vascular supply (Table 1, Fig. 2). Inferior to the dentate line, the anal canal is lined by non-keratinised stratified squamous epithelium - anal pecten (Li et al., 2015; Fontem et al., 2020). Internal haemorrhoidal plexus is located in fibrous 
Table 1. Nerve supply and lymphatics in the anal canal

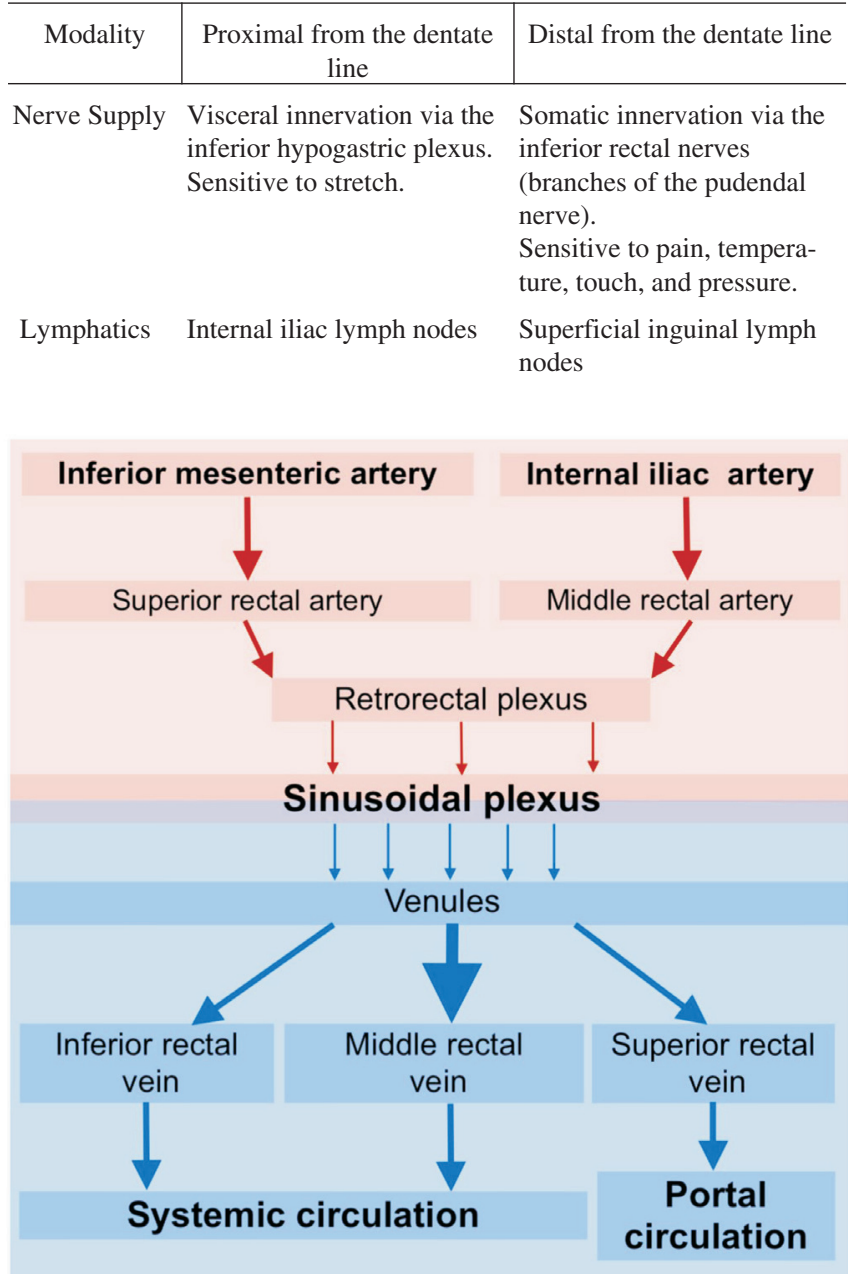

Fig. 2. Arterial supply and venous drainage of the anal canal.

connective tissue above the dentate line and below the anorectal ring. The plexus consists of arterioles, venules, and arterio-venular functional anastomoses (Genova et al., 2019). Furthermore, capillaries appear in the mucosal lamina propria immediately beneath the epithelium (Lohsiriwat, 2018; Fontem et al., 2020). As anatomically authentic rectal epithelium, it secrets mucus and is not innervated by visceral pain fibers. Therefore, internal haemorrhoids are not painful (Genova et al., 2019).

\section{PATHOPHYSIOLOGY OF HAEMORRHOIDS}

It is considered that haemorrhoids primarily result from abnormally congested vascular channels within descended anal cushions (Li et al., 2015; Lohsiriwat, 2018; Erol et al., 2020; Fontem et al., 2020). We do not know if a haemorrhoid is primary or secondary, because every patient suffering from haemorrhoidal disease demonstrates features of the initial developmental stage. We know that haemorrhoids are normal structures of the human body, but the disease arises when there are complaints and symptoms. The internal haemorrhoids arise from internal haemorrhoidal plexus when three soft haemorrhoids enlarge and transform into

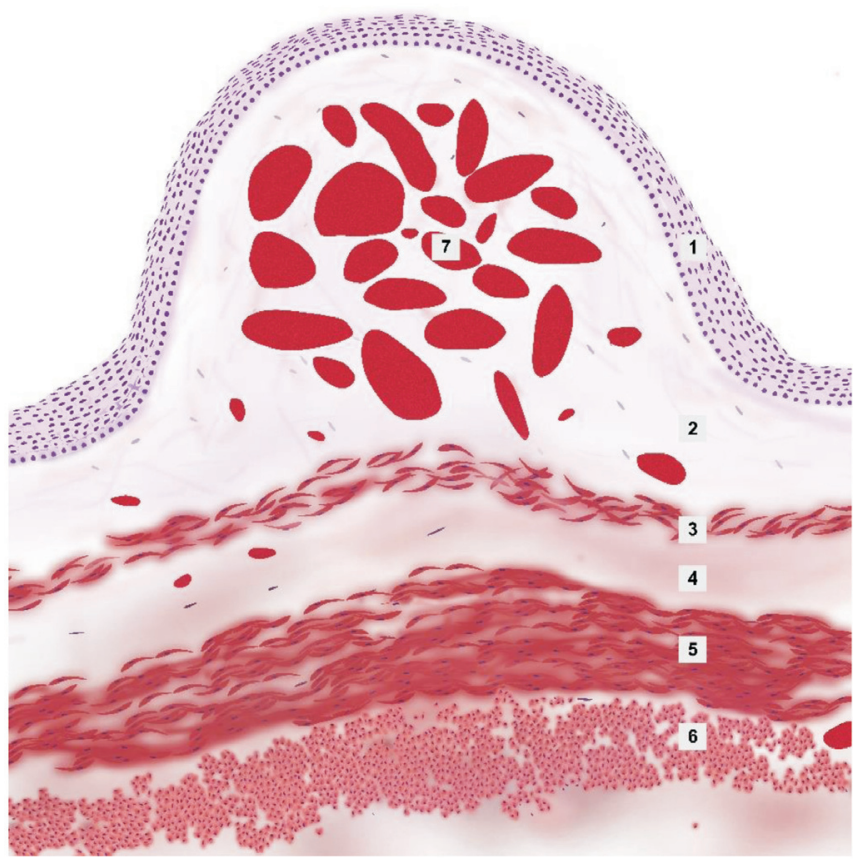

Fig. 3. Histology of anal cushion. 1 - stratified squamous epithelium; 2 fibrous connective tissue; 3 - mucosa muscle (gradually becomes indistinct); 4 - the suspensory ligament or Park's ( $3 \& 4$ forms the muscle of Trietz's); 5 - internal anal sphincter; 6 - conjoined longitudinal muscle; 7 - dilated vascular channels.

anal nodules. In turn, the external haemorrhoids arise from external plexus. A contradicting theory describes the external haemorrhoids as extensions of internal ones (Lunniss et al., 2004). However, the definition of the disease has certain incompleteness, since anal cushions are named "haemorrhoids" when they bleed and/or prolapse (Lohsiriwat, 2018).

Peculiarities of the vascular supply of the anal cushion. Microscopically, congested vascular channels of the anal cushion are described as sinusoids. (Margetis, 2019). Previous studies have demonstrated the existence of arteriovenous communications, thus explaining why haemorrhoidal bleeding is bright red and has the same $\mathrm{pH}$ as arterial blood (Margetis, 2019). Sinusoids form a spongy capillary network that resembles penile erectile tissue (Trenti et al., 2019). Sinusoids receive arterial blood from the superior and middle rectal arteries, oxygenate the nonvascular part of the anal cushion, and then venous blood through tiny veins drains into superior and middle rectal veins. Systemic and portal venous circulation is mixed inside the sinusoids (Fig. 3 ). Capillaries and tiny arterioles of the mucosal lamina propria are the sources of bleeding when the anal cushions turn into haemorrhoids. The preferential arterial supply into specific locations of the upper anus favours the development of the sinusoidal plexus in these locations almost exclusively - directly to principal locations of arterial branches in the submucosal tissue: left lateral (3 o'clock), right anterior (11 o'clock), and right posterior (7 o'clock) (Lohsiriwat, 2018; Trenti et al., 2018, Trenti et al., 2019; Fontem et al., 2020). In contrast, external haemorrhoids commonly develop in the right posterior quadrant (RayOffor et al., 2019). 
Muscles of the anus, and their contribution to defecation. Normal anal cushions are not real protrusions. They look more like the unavoidable creases appearing during the closure of the anal canal and disappearing when the anal canal widens during defecation. Trietz's muscle tightly maintains the cushions in their normal position; its deterioration is considered one of the most important pathogenic factors in the formation of haemorrhoids (Margetis, 2019; Fontem et al., 2020). Trietz's muscle consists of two parts: anal cushion muscle, whose bundles subside between sinusoids, fixing the cushions to the internal anal sphincter, while the Park's ligament penetrates the internal sphincter and fixes connective tissue with vascular channels to the conjoined longitudinal muscle (Lohsiriwat, 2018). Anatomically, the conjoined longitudinal muscle is not a part of the anal cushion, but it supports the internal and external sphincter and fixes anorectum to the pelvis. Certain anatomical features contribute to the fixation of the anal cushions above the dentate line, the maintenance of their usual size, and the prevention of their prolapse. These include the integrity of connective tissue housing the sinusoids, Trietz's muscle and conjoined longitudinal muscle, the sphincter-like structures present in the terminal arterioles and the fairly small-caliber arteries (Lohsiriwat, 2018; Trenti et al., 2018, Trenti et al., 2019; Fontem et al., 2020). These anatomical structures prevent the hyperperfusion of sinusoids.

\section{CURRENT THEORIES EXPLAINING THE DEVELOP- MENT OF HAEMORRHOIDAL DISEASE}

A growing body of evidence suggests the existence of several theories, but none of which fully explains the development of haemorrhoidal disease. These proposals are categorised into four groups: sliding anal cushions, vascular abnormality, rectal redundancy, and increased pressure on anorectal vascular plexus (described in Lohsiriwat, 2018).

Sliding anal cushions. Sliding anal cushions can explain the prolapse of haemorrhoids, but they cannot explain repeated bleeding episodes in patients with nonprolapsed haemorrhoids. They could be secondary because of destructive changes in connective tissue and could be associated with aging (Wallner, 2008; Stokr, 2009; Sardinas et al., 2016). Repeated and successive cycles of elongation and shortening of Trietz's muscle following chronically strained defecations result initially in its relaxation and ultimately in its disintegration (Mott et al., 2018). These muscular bundles may also disintegrate because of pelvic floor weakness with increasing age, but this theory does not explain the involvement of young patients (years) with prolapsed haemorrhoids, without previous operations, deliveries, etc. A possible explanation is the already utilised capacity of Trietz's muscle in these subjects. Fragmentation of the anal cushion muscle in patients with haemorrhoidal disease is often accompanied by vascular changes. Rubber band ligation, plication of haemorrhoids, and haemorrhoidectomy are commonly used in the case of haemorrhoidal disease caused by sliding anal cushions (Guttadauro et al., 2018; Mott et al., 2018; Rubbini et al., 2019; Gardner et al., 2020).
Vascular changes in haemorrhoids. Vascular abnormality comprises a heterogeneous group and includes anorectal varices, arterial hyperperfusion in the sinusoids, vascular hyperplasia, venous distension, and hypertension. It has been proved recently that structurally haemorrhoids are not varicosities (Margetis, 2019). Previous studies confirmed the association of anorectal varices with portal hypertension in cirrhotic patients ( $\mathrm{Li}$ et al., 2015). However, later studies showed the absence of differences in the hepatic venous pressure in cirrhotic patients with and without anorectal varices (Ray-Offor et al., 2015). Sinusoids are hyperperfused and overloaded, whereas connective tissue loses its capacity to support the vascular network and impedes venous return (Kuivaniemi et al., 2019). Structurally, vascular beds reveal hyperplasia paralleled by CD105 overexpression (Aigener et al., 2009; Lohsiriwat, 2018). Furthermore, a significant increase in the diameter of the terminal branches of the superior rectal artery of patients with haemorrhoids accompanied by a greater blood flow compared to healthy volunteers has been confirmed (Tian et al., 2018). Previously, other authors demonstrated the presence of a correlation between the caliber of the vessel and the grade of haemorrhoids (Aigener et al., 2006; Hoynela et al., 2016). Furthermore, the presence of various vasodilatory factors in haemorrhoids has been demonstrated. A significant increase in nitric oxide synthase was observed in studies conducted by Han et al. (2005). Simultaneously, other authors demonstrated changes in the vascular endothelin receptor and transforming growth factor $\beta$ receptor expression in patients with and without haemorrhoids (Chyng et al., 2004; Li et al., 2015; Lohsiriwat et al., 2017). Changes in anal cushion tissue have been described in haemorrhoids presenting with venous hypertension. Commonly, these multiple changes include inflammatory infiltration, release of proteolytic enzymes and inflammatory mediators leading to maintenance of inflammation, alteration of the cellular constituents of the vascular wall, microangiopathy, vascular dilatation, and progressive weakness of the bulk of connective tissue (Bergan et al., 2006). The conventional therapeutic modalities used in the case of vascular changes present in haemorrhoids are applications of oral or topical phlebotonics, sclerotherapy, laser therapy, and Doppler-guided haemorrhoidal artery ligation (Giamundo et al., 2016; Cocorullo et al., 2017; Garg, 2017).

Rectal redundancy and its role in haemorrhoidal disease. Rectal redundancy more likely is an effect than the cause of haemorrhoidal disease. The presence of previous prolapse surgery is demonstrated in $27.3 \%$ of cases of women undergoing vaginal urogynecology surgery and concurrent haemorrhoidectomy (Casas-Puig et al., 2019). Abnormalities in quality, composition, and metabolism of collagen can explain the development of protrusion of anal cushions and haemorrhoid formation. Structurally, the major collagenous types identified thus far in the bulk of connective tissue of the anal cushion are collagen types I and III. Commonly, collagen type I forms thick bundles, whereas type III - a delicate network. A decreased level of collagen type I and an increased level of collagen type III 
expression were observed in haemorrhoidal specimens when compared to normal anal cushions (Willis et al., 2010; Nasseri et al, 2015). Furthermore, a strong decrease in collagen protein synthesis is evident in subjects with grade III and IV of the haemorrhoidal disease (Willis et al., 2010; Nasseri et al., 2015). Commonly, rectal redundancy is corrected by the use of stapled haemorrhoidopexy and a special procedure for prolapse and haemorrhoids (PPH) (Sturiale et al., 2018).

Increased pressure on anorectal vascular plexus. Increased pressure on anorectal vascular plexus is a chronic rise in intraabdominal pressure when even cough in combination with the absence of valves within rectal veins can limit venous drainage from sinusoids during defecation, leading to abnormal dilatation of the arterio-venous anastomoses in internal haemorrhoidal plexus (Li et al., 2015; Ray-Offor et al., 2015). Defecation habits change over time to sitting down instead of squatting. This position, in turn, does not allow to straighten the anorectal angle, making the pushing process impossible without increasing the intraabdominal pressure (Margetis, 2019). Increased intraabdominal pressure elevates, in turn, the intrarectal pressure acting on the venous plexuses and affecting drainage causing stasis, and haemorrhoid formation. Previous studies suggested increased intrarectal pressure in patients with functional constipation or obstructed defecation disorder (Aigener et al., 2009; Lohsiriwat, 2018). The recommended therapeutic approach is dietary and lifestyle modification (Cocorullo et al., 2017; Garg et al., 2017).

\section{CLASSIFICATION OF HAEMORRHOIDAL DISEASE}

The necessity of a new classification identifying etiology, symptoms of prolapse, symptomatology, enteropathogenesis, and gender characteristics has been proposed by both clinicians and researchers (Rubbini et al., 2019). Nowadays, coloproctologists use numerous updated classifications of haemorrhoidal disease, but in fact they are modifications of the Golinger's classification (Table 2). Clinical symptoms vary greatly, from bleeding to ulceration and mucosal atrophy, and the aforementioned manifestations depend on the grade of the haemorrhoidal disease (Lohsiriwat, 2015). Haemorrhoids appear as normally or near-normally structured with prominent and engorged vasculature, but not prolapsed when grade I is diagnosed (Lunnis et al., 2004; Hassan et al., 2016; Garg, 2017; Kreger et al., 2018; Lohsiriwat, 2018; Mott et al., 2018; Margetis, 2019; Rubbini et al., 2019; Gardner et al., 2020). Development of some symptoms, prolapsed haemorrhoidal tissue when strained, but spontaneously reduced, are characteristics of the grade II (Lunnis et al., 2004; Hassan et al., 2016; Garg, 2017; Lohsiriwat, 2018; Mott et al., 2018; Margetis, 2019; Rubbini et al., 2019; Gardner et al., 2020) (Fig. 4). In turn, the appearance of itching, staining, soiling, and swelling symptoms, the presence of haemorrhoidal tissue prolapsed beyond the dentate line when strained, and reduced manually, are characteristics of grade III (Lunnis et al., 2004; Hassan et al., 2016; Garg, 2017; Lohsiriwat, 2018; Mott et

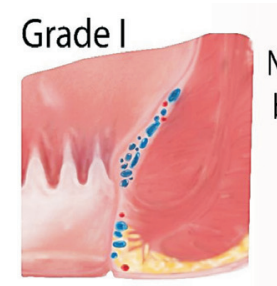

Normal appearance externally, bleeding but not prolapsing

Grade II

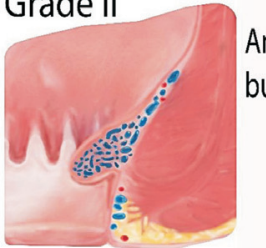

Anal cushions prolapse on straining but reduces spontaneously

Grade III

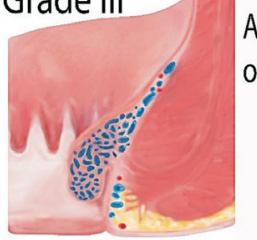

Anal cushions prolapse on straining or exertion and require manual reduction

Grade IV

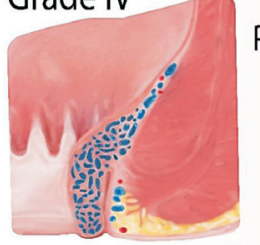

Permanent prolapse, irreducible

Fig. 4. The grades distinguished for haemorrhoidal disease.

al., 2018; Margetis, 2019; Rubbini et al., 2019; Gardner et al., 2020) (Fig. 4). Upon progression toward grade IV, the prolapsed haemorrhoidal tissue becomes evident and cannot be reduced manually. Gradually, chronic inflammatory changes with maceration, mucosal atrophy, friability, and ulceration develop (Lunnis et al., 2004; Hassan et al., 2016; Garg, 2017; Lohsiriwat, 2018; Mott et al., 2018; Margetis, 2019; Rubbini et al., 2019; Gardner et al., 2020) (Fig. 4).

\section{SURGERY AND LESS INVASIVE TECHNOLOGIES APPLICABLE FOR THE TREATMENT OF HAEMOR- RHOIDAL DISEASE}

Indications for surgical treatment are based on the grade of haemorrhoidal disease (Table 2). Surgical treatment is indicated for grade III and IV internal haemorrhoids and thrombosed external haemorrhoids with persistent symptoms. A perfect operation for haemorrhoids must have minimal postoperative pain and complications, with no risk of recurrence development (Rubbini et al., 2019). It has been shown that age itself is not correlated with postoperative complications (Yamamoto et al., 2020). Different methods of surgical and invasive treatment of haemorrhoids are compared below (Table 3).

Excisions of haemorrhoids. Commonly excision of haemorrhoidal tissue is performed within the first $48 \mathrm{~h}$ of symptoms of thrombosing. Complete excision of a haemorrhoid with associated skin is advised when incision and drainage 
Table 2. Goligher's classification

\begin{tabular}{rll}
\hline Grade & \multicolumn{1}{c}{ Definition } \\
\hline I & Normal appearance externally, bleeding but not prolapsing \\
II & Anal cushions prolapsed on straining but reduce spontaneously \\
III & $\begin{array}{l}\text { Anal cushions prolapsed on straining or exertion and require } \\
\text { manual reduction }\end{array}$ \\
IV & $\begin{array}{l}\text { Permanent prolapse, irreductible, thrombosis, incarceration, } \\
\text { necrosis }\end{array}$
\end{tabular}

Table 3. Pathophysiological treatment possibility

\begin{tabular}{l|l|l}
\hline Aetiological factor & \multicolumn{1}{c|}{ Pathophysiology } & $\begin{array}{c}\text { Possibility of invasive } \\
\text { treatment }\end{array}$ \\
\hline $\begin{array}{l}\text { Descended anal } \\
\text { cushions }\end{array}$ & Sliding anal cushion & $\begin{array}{l}\text { Rubber band ligation, } \\
\text { plication of haemor- } \\
\text { rhoids, and } \\
\text { haemorrhoidectomy }\end{array}$ \\
$\begin{array}{l}\text { Existence of } \\
\text { arterio-venous } \\
\text { communications }\end{array}$ & $\begin{array}{l}\text { Vascular abnormality } \\
\text { includes anorectal } \\
\text { varices, arterial } \\
\text { hyperperfusion in the } \\
\text { sinusoids, vascular } \\
\text { hyperplasia, venous } \\
\text { distension, and }\end{array}$ & $\begin{array}{l}\text { Sclerotherapy, laser } \\
\text { therapy, and Doppler- } \\
\text { guided haemorrhoidal } \\
\text { artery ligation }\end{array}$ \\
& $\begin{array}{l}\text { Rectal redundancy } \\
\text { Trietz's muscle } \\
\text { deterioration }\end{array}$ & $\begin{array}{l}\text { Stapled } \\
\text { haemorrhoidopexy and a } \\
\text { special procedure for } \\
\text { prolapse and haemor- } \\
\text { rhoids (PPH) }\end{array}$ \\
& &
\end{tabular}

are ineffective (Wang et al., 2018; Gardner et al., 2020). The results of a study published recently suggest the disappearance of symptoms in 3.9 days after excision, and 24 days after the use of nonoperative treatment modalities (Gardner et al., 2020).

Ferguson excision haemorrhoidectomy is the most common type of haemorrhoidectomy. In this conventional operation, the prolapsed haemorrhoid connective tissue and congested blood vessels are removed, whereas the anoderma is preserved, and the internal sphincter is protected with a totally inverted sliding process (Trenti et al., 2018). A sufficient body of evidence suggests that the Ferguson technique induces faster healing (Gardner et al., 2019). Among complications associated with the use of the Ferguson technique, incontinence and anal stenosis (Rakinic, 2018; Gardner et al., 2019), and severe postoperative pain are most often reported (Lohsiriwat, 2015; Xu et al., 2015). The severity of complications depends on the amount of excised tissue and sphincter damage. It is safe for grade III to IV disease and shows better continence than using Milligan-Morgan haemorrhoidectomy (Lohsiriwat, 2015).

Finally, Milligan-Morgan haemorrhoidectomy is an elliptical incision from the perianal skin to the anal canal, leaving wounds open (Gardner et al., 2019). This technique is preferred for gangrenous haemorrhoids, with pedicle ligation after separation of haemorrhoidal tissues from the sphincter (Bhatti et al., 2016; Rakinic, 2018; Gardner et al., 2019). For better outcome, the surgeon should identify Park's liga- ment (Zoulamoglou et al., 2017). Urinary retention, bleeding, fecal or flatus incontinence, perianal wetness, anal stenosis, and recurrence are complications demonstrated when using this technique (Kendirci et al., 2018). The severity of pain depends on the number of muscular and collagenous bundles excised, and the method commonly is safe for grades III to IV (Lohsiriwat, 2015; Wang et al., 2018).

Treatment of haemorrhoids with the use of a stapling device. In stapled haemorrhoidopexy, the loose connective tissue of mucosa and the enlarged haemorrhoidal nodules above the dentate line contributing to the prolapse are excised (Cristea et al., 2020). According to the technique, a special circular device - a stapler excises a ring of redundant mucosa and fixes the haemorrhoidal plexus $4 \mathrm{~cm}$ above the dentate line without any sphincter tissues. This operation corrects some abnormal pathogenic pathways: prolapse is resected, the capacity of nodules is reduced, and the vessels supplying the internal haemorrhoidal plexus are ligated, thus limiting the blood supply to the nodules (Lohsiriwat, 2015). The complications reported in stapled haemorrhoidopexy are bleeding, injury of the sphincter muscle, dehiscence of anastomotic line, stenosis, and recto-vaginal fistula (Gardner et al., 2020). However, partial stapled haemorrhoidopexy reduces postoperative pain and urgency, there is minimal risk of development of anal stenosis, and better postoperative anal continence (Lin et al., 2019). Estimated overall complication rates of stapled haemorrhoidopexy range from 3.3 up to $81 \%$, with 5 mortalities documented (Porrett et al., 2015). Interestingly, very low rates of bleeding were demonstrated in the postoperative period after stapled haemorrhoidopexy followed by the use of biological glue in patients with cardiac stents and risk of bleeding (Pirolla et al., 2017). Simultaneously, stapled haemorrhoidopexy has been recognised as a technique providing higher rates of recurrence (Araujo et al., 2016; Lin et al., 2019).

The development of more frequent prolapsing of the tissue, already in two years after stapled haemorrhoidopexy, was reported in a randomised study comparing this technique to opened haemorrhoidectomy (Schneider et al., 2019; Gardner et al., 2020). Furthermore, a high rate of recurrence and incontinence after the use of stapled haemorrhoidopexy was demonstrated in a long-term follow-up study (Sturiale et al., 2018; Du et al., 2019).

Application of the LigaSure ${ }^{\mathrm{TM}}$ technology for the treatment of haemorrhoidal disease. LigaSure ${ }^{\mathrm{TM}}$ technology is based on a unique combination of pressure and energy to create a consistent seal with size up to $7 \mathrm{~mm}$ in vascular structures. Largely, the complications appearing by using these new technologies are not completely understood. However, the development of minimal adhesion and tissue damage due to thermal exposure have been reported (Champagne et al., 2015). Previous studies demonstrated the safety of the aforementioned technology with no risk of development of anal stenosis, when comparing the use of vessel-sealing devices and conventional haemorrhoidectomy (Kendirci et al., 2018; Mott et al., 2018). 
Application of the Harmonic Scalpel ${ }^{\mathrm{TM}}$ technology for the treatment of haemorrhoidal disease. The Harmonic Scalpe ${ }^{\mathrm{TM}}$ is another novel technology used for the treatment of haemorrhoidal disease by causing coagulation. Vibrating at $55000 \mathrm{~Hz}$, structures up to $7 \mathrm{~mm}$ form adhesions. It is a safe, rapid, and effective method for the treatment of haemorrhoid grades III and IV (Kim et al., 2019). Previous studies reported the presence of some tissue damage, alterations in peripheral nerves, and vascular thrombosis (Giamundo, 2016; Cristea et al., 2020). However, no difference was found in postoperative pain, analgesic requirement, and time until complete wound healing (Talha et al., 2017).

Nonexcisional surgical techniques for the treatment of haemorrhoidal disease Doppler-guided haemorrhoidal artery ligation is a method that offers a tailored individualised therapy, since it locates the feeding terminal branch of the superior rectal artery (SRA) that supplies each haemorrhoidal nodule, ultimately performing targeted suture ligation (Yilmaz et al., 2012; Trenti et al., 2019). The advantage of the method is the preservation of the anatomy and physiology of the anal canal (Tsunoda et al., 2015; Hoynela et al., 2016; Gachabayov et al., 2019). It is especially effective for grades II and III of haemorrhoidal disease (Giomundo, 2016; Grag, 2017). Consequently, the increased blood supply to the anal cushion is diminished, its engorgement is prevented, its size is decreased, and it is ultimately firmly fixed to the floor of the upper surgical anal canal (Yilmaz et al., 2016; Trenti et al., 2017). This alternative operation technique has been proven to relieve the patient's symptoms, with only minor complications and rare relapses (Ratto et al., 2017; Trenti et al., 2019). The reported recurrence rate for grade IV haemorrhoids is up to $60 \%$ (Yilmaz et al., 2012; Simillis et al., 2015; Giamundo et al., 2016; Popov et al., 2019). Simultaneously, the one-year recurrence rate after treatment is $10 \%$ for prolapse and bleeding (Lohsiriwat, 2015; Leung et al., 2017; Ratto et al., 2017). The number of relapses in such a short period of time imposes additional obligations on the proper categorisation of patients selected for each method. Transanal haemorrhoidal dearterialisation (THD) is associated with a shorter need for postoperative analgesia compared with vessel-sealing device haemorrhoidectomy (Figueiredo et al., 2016; Trenti et al., 2019). For haemorrhoidal disease grade III, the results are the same as treating with Milligan-Morgan technique (Genova et al., 2019). However, THD and stapled haemorrhoidopexy have fewer anal stenosis than open haemorrhoidectomy and the harmonic scalpel (Kim et al., 2019). Furthermore, THD has lower rates of postoperative pain (Leung et al., 2017; Du et al., 2019; Popov et al., 2019; Gachabayov et al., 2019). In a study of conventional haemorrhoidectomy and THD, one year after the operation, no significant differences were found in bleeding, prolapse, and pain (Figueiredo et al., 2016; Ratto et al., 2017; Trenti et al., 2019; Xu et al., 2019).

Finally, SRA embolisation is percutaneous embolisation with metallic coils and synthetic polyvinyl alcohol particles. Haemorrhoidal artery coil embolisation was found to be a safe and effective treatment for grade II and III haemorrhoids (Zakharchenko et al., 2016; Moussa et al., 2017; Tradi et al., 2019). There were no significant early or late complications. Reduction of the size of vasculature was observed in $43 \%$ of patients, with the amount of blood flow in haemorrhoidal plexus reduced by almost 50\% (Zakharchenko et al., 2016; Ventorini et al., 2018; Moussa et al., 2020). Embolisation was found, not to leading to ischemia in patients with symptomatic haemorrhoidal disease (Zakharchenko et al., 2016; Trenti et al., 2018; Tradi et al., 2019; Ferrer Puchol et al., 2020 ).

\section{CONCLUSION}

Evidence accumulated from numerous studies on haemorrhoidal disease suggests that the exact aetiology and pathophysiology are still unclear. The pathophysiology is most likely multifactorial and complex. No single factor or possible theory in isolation is confirmed with $100 \%$ probability. The classification of haemorrhoidal disease should be submitted to revision by including aetiological factors, emerging symptom, age, gender, and concomitant diseases of the patient. Nowadays, there are very wide possibilities of invasive therapy, however, by linking them with the pathophysiological factor we can achieve better results in the long term. The next challenge will be to find a factor that can be used to determine the predisposition, the probability of the disease, and to find direct factors influencing the proliferative form of the haemorrhoidal disease in young people, despite an active lifestyle, normal bowel movement, without excess weight, childbirth, and venous insufficiency in the lower extremities. Probably, these factors will prove to be associated with a prolonged vertical position during the day or increased training of the upper part of the body.

\section{REFERENCES}

Aigener, F., Bodner, G., Gruber, H., Conrad, F., Fritsch, H., Margreiter, R., Bonatti, H. (2006). The vascular nature of hemorrhoids. J. Gastrointest Surg., 10, 1044-1050.

Aigner, F., Gruber, H., Conrad, F., Eder, J., Wedel, T., Zelger, B., Engelhardt, V., Lametschwandtner, A., Wienert, V., Böhler, U., Margreiter, R., Fritsch, H. (2009). Revised morphology and hemodynamics of the anorectal vascular plexus: impact on the course of hemorrhoidal disease. Int. J. Colorect. Dis., 24 (1), 105-113.

Araujo, S. E., Horcel, L. A., Seid, V. E., Bertoncini, A. B., Klajner, S. (2016). Long term results after stapled hemorrhoidopexy alone and complemented by excisional hemorrhoidectomy: A retrospective cohort study. Brazilian Arch. Digest. Surg., 29 (3), 159-163.

Barleben, A., Mills, S. (2010). Anorectal anatomy and physiology. Surg. Clin. North Amer., 90 (1), 1-15.

Bergan, J. J., Schmid-Schonbein, G. W., Smith, P. D., Nicolaides, A. N., Boisseau, M. R., Eklof, B. (2006). Chronic venous disease. North Engl. J. Med., 355, 488-498.

Bhatti, M. I., Sajid, M. S., Baig, M. K. (2016). Milligan-Morgan (Open) versus Ferguson haemorrhoidectomy (closed): A systematic review and meta-analysis of published randomized, controlled trials. World J. Surg., 40 (6), 1509-1519.

Casas-Puig, V., Bretschneider, E. C., Ferrando, C. A. Postoperative adverse events in women undergoing concurrent hemorrhoidectomy at the time of 
urogynecologic surgery (2019). Female Pelvic Med. Reconstr. Surg., 25 (2), 88-92.

Chang, S. S., Sung, F. C., Lin, C. L., Hu, W. (2017). Association between hemorrhoid and risk of coronary heart disease: A nationwide populationbased cohort study. Medicine (Baltimore), 96 (31), e7662.

Champagne, B. J., Stein, S. L., Haridas, M., Ermlich, B., Hoffman, L., Lee, J., Johnson, E. K., Steele, S. R. (2015). Novel operative anoscope for Ferguson hemorrhoidectomy: A feasibility study and comparative cohort analysis. Surg. Innov., 22 (2), 149-154.

Chung, Y. C., Hou, Y. C., Pan, A. C. (2004). Endoglin (CD105) expression in the development of hemorrhoids. Eur. J. Clin. Invest., 34, 107-112.

Cocorullo, G., Tutino, R., Falco, N., Licari, L., Orlando, G., Fontana, T., Raspanti, C., Salmone, G., Scerrino, G., Gallo, G., Trompetto, M., Gulotta, G. (2017). The non-surgical management for hemorrhoidal disease. A systemic review. Il Giornale di chirurgia, 38 (1), 5-14.

Cristea, C., Lewis, C. R. (2019). Hemorrhoidectomy. StatPearls Publishing. Available from: https://www.ncbi.nlm.nih.gov/books/NBK549864/ (accessed 12.01.2021)

Du, T., Quan, S., Dong, T., Meng, Q. ( 2019). Comparison of surgical procedures implemented in recent years for patients with grade III and IV hemorrhoids: A network meta-analysis. Int. J. Colorect. Dis., 34 (6), 1001-1012.

Erden, A. (2018). MRI of anal canal: Normal anatomy, imaging protocol, and perianal fistulas: Part 1. Abdom Radiol., 43, 1334-1352.

Kisli, E., Kemik, A., Sumer, A., Kemik, O. (2020). Matrix metalloproteinases in pathogenesis of hemorrhoidal disease. Amer. Surg., 79 (11), 1181-1184.

Ferrer Puchol, M. D., Esteban Hernández, E., Blanco González, F. J., Ramiro Gandia, R., Solaz Solaz, J., Pacheco Usmayo, A. (2020). Selective intra-arterial embolization to treat hemorrhoids. Radiologia, 62 (4), 313-319 (in Spanish).

Fontem, R. F., Eyvazzadeh, D. (2020). Internal hemorrhoid. StatPearls Publishing; Available from:

https://www.ncbi.nlm.nih.gov/books/NBK537182/ (accessed 12.01.2021).

Figueiredo, M. N., Campos, F. G. (2016). Doppler-guided hemorrhoidal dearterialization/transanal hemorrhoidal dearterialization: Technical evolution and outcomes after 20 years. World J. Gastrointest. Surg., 8 (3), 232-237.

Gachabayov, M., Angelos, G., Bergamaschi, R. (2019). THD Doppler: A reliable surgical procedure to treat hemorrhoids. Surg. Technol. Int., 34, 189-193.

Gardner, I. H., Siddharthan, R. V., Tsikitis, V. L. (2020). Benign anorectal disease: Hemorrhoids, fissures, and fistulas. Ann. Gastroenterol., 33 (1), 9-18.

Garg, P. (2017). Hemorrhoid treatment needs a relook: More room for conservative management even in advanced grades of hemorrhoids. Indian J. Surg., 79 (6), 578-579.

Genova, P., Damiano, G., Lo Monte, A. I., Genova, G. (2019). Transanal hemorrhoidal dearterialization versus Milligan-Morgan hemorrhoidectomy in grade III/IV hemorrhoids. Ann. Ital. Chir., 90, 145-151.

Giamundo, P. (2016). Advantages and limits of hemorrhoidal dearterialization in the treatment of symptomatic hemorrhoids. World $J$. Gastrointest. Surg., 8 (1), 1-4.

Godeberge, P., Sheikh, P., Zagriadskii, E., Lohsiriwat, V., Montano, A. J., Košorok, P., De Schepper, H. (2020). Hemorrhoidal disease and chronic venous insufficiency: Concomitance or coincidence; results of the $\mathrm{CHO}$ RUS study (Chronic venous and Hemorrhoidal diseases evaluation and Scientific research). J. Gastroenterol. Hepatol., 35 (4), 577-585.

Guo, M., Li, D. (2007). Pelvic floor images: Anatomy of the levator ani muscle. Dis. Colon Rectum., 50 (10), 1647-1655.

Guttadauro, A., Maternini, M., Chiarelli, M., Lo Bianco, G., Pecora, N., Gabrielli, F. (2018). Evolution in the surgical management of hemorrhoidal disease. Annali Italiani Di Chirurgia., 89, 101-106.
Halverson, A. (2007). Hemorrhoids. Clinics Colon Rect. Surg., 20 (2), $77-85$.

Han, W., Wang, Z. J., Zhao, B., Yang, X. Q., Wang, D., Wang, J. P., Tang, X. Y., Zhao, F., Hung, Y. T. (2005). Pathologic change of elastic fibers with difference of microvessel density and expression of angiogenesis- related proteins in internal hemorrhoid tissues. Zhonghua Wei Chang Wai Ke Za Zhi., 8, 56-59.

Hoyuela, C., Carvajal, F., Juvany, M., Troyano, D., Trias, M., Martrat, A., Ardid, J., Obiols, J. (2016). HAL-RAR (Doppler guided haemorrhoid artery ligation with recto-anal repair) is a safe and effective procedure for haemorrhoids. Results of a prospective study after two-years follow-up. Int. J. Surg., 28, 39-44.

Hu, W. S., Lin, C. L. (2017). Hemorrhoid is associated with increased risk of peripheral artery occlusive disease: A nationwide cohort study. $J$. Epidemiol., 27 (12), 574-577.

Kendirci, M., Şahiner, İ. T., Şahiner, Y., Güney, G. (2018). Comparison of effects of vessel-sealing devices and conventional hemorrhoidectomy on postoperative pain and quality of life. Med. Sci. Monitor, 24, 2173-2179.

Kinugasa, Y., Arakawa, T., Murakami, G., Fujimiya, M., Sugihara, K (2014). Nerve supply to the internal anal sphincter differs from that to the distal rectum: An immunohistochemical study of cadavers. Int. J. Colorect. Dis., 29 (4), 429-436.

Kreger, J., Guttenplan, M. (2018). Hemorrhoidal banding and anesthesia partnerships as ancillary services to gastroenterology practices. Gastroenterology \& Hepatology., 14 (8), 488-490.

Kuivaniemi, H, Tromp, G. (2019). Type III collagen (COL3A1): Gene and protein structure, tissue distribution, and associated diseases. Gene, 707, $151-171$.

Leung, A., Cheung, T., Tung, K., Tsang, Y. P., Cheung, H., Lau, C. W., Tang, C. N. (2017). A prospective randomized controlled trial evaluating the short-term outcomes of transanal hemorrhoidal dearterialization versus tissue-selecting technique. Techn. Coloproctolol., 21 (9), 737-743.

Lin, H. C., He, Q. L., Shao, W. J., Chen, X. L., Peng, H., Xie, S. K., Wang, X. X., Ren, D. L. (2019). Partial stapled hemorrhoidopexy versus circumferential stapled hemorrhoidopexy for grade III to IV prolapsing hemorrhoids: A randomized, noninferiority trial. Dis. Colon Rectum, 62 (2), 223-233.

Li, S. L., Jing, F. Y., Ma, L. L., Guo, L. L., Na, F., An, S. L., Ye, Y., Yang, J. M., Bao, M., Kang, D., Sun, X. L., Deng, Y. J. (2015). Myofibrotic malformation vessels: Unique angiodysplasia toward the progression of hemorrhoidal disease. Drug Des. Devel. Ther., 9, 4649-4656.

Lunniss, P. J., Mann, C. V. (2004). Classification of internal hemorrhoids: Discussion paper. Colorect. Dis., 6, 226-232.

Lohsiriwat, V. (2015). Treatment of hemorrhoids: A coloproctologist's view. World J. Gastroenterol., 21, 9245-9252.

Lohsiriwat, V., Scholefield, J. H., Wilson, V. G., Dashwood, M. R. (2017). Endothelin-1 and its receptors on haemorrhoidal tissue: A potential site for therapeutic intervention. Brit. J. Pharmacol., 174 (7), 569-579.

Lohsiriwat, V. (2018) Anatomy, physiology, and pathophysiology of hemorrhoids. In: Ratto, C., Parello, A., Litta, F. (eds). Hemorrhoids. Coloproctology, Vol 2. Springer, Cham, pp. 9-17.

Margetis, N. (2019). Pathophysiology of internal hemorrhoids. Ann. Gastroenterol., 32 (3), 264-272.

Mott, T., Latimer, K., Edwards, C. (2018). Hemorrhoids: Diagnosis and treatment options. Amer. Fam. Physician., 97 (3), 172-179.

Moussa, N., Sielezneff, I., Sapoval, M., Tradi, F., Del Giudice, C., Fathallah, N., Pellerin, O., Amouyal, G., Pereira, H., de Parades, V., Vidal, V. (2017). Embolization of the superior rectal arteries for chronic bleeding due to haemorrhoidal disease. Colorectal Dis., 19 (2), 194-199.

Moussa, N., Bonnet, B., Pereira, H., Pechmajou, L., Pellerin, O., Abed, A., Del Giudice, C., Dean, C., Bouda, D. de Parades, V., Fathallah, N., Sapoval, M. (2020). Mid-term results of superior rectal artery and coils for hemorrhoidal embolization with particles bleeding. Cardiovasc. Intervent. Radiol., 43 (7), 1062-1069. 
Muranaka, F., Nakajima, T., Iwaya, M., Ishii, K., Higuchi, K., Ogiwara, N., Miyagawa, S., Ota, H. (2018). A comparative immunohistochemical study of anal canal epithelium in humans and swine, focusing on the anal transitional zone epithelium and the anal glands. Anatom. Rec., 301 (5), 796-805.

Nasseri, Y. Y., Krott, E., Van Groingen, K. M., Berho, M., Osborne, M. C., Wollman, S., Weiss, E. G., Wexner, S. D. (2015). Abnormalities in collagen composition may contribute to the pathogenesis of hemorrhoids: Morphometric analysis. Tech. Coloproctol., 19, 83-87.

Peery, A. F., Sandler, R. S., Galanko, J. A., Bresalier, R. S., Figueiredo, J. C., Ahnen, D. J., Barry, E. L., Baron, J. A. (2015). Risk factors for hemorrhoids on screening colonoscopy. PLos One, 10 (9), e0139100.

Petros, P., Swash, M., Bush, M., Fernandez, M., Gunnemann, A., Zimmer, M. (2012). Defecation 1: Testing a hypothesis for pelvic striated muscle action to open the anorectum. Techn. Coloproctol., 16 (6), 437-443.

Pirolla, E. H., Pirolla, F., Ribeiro, F. (2017). PPH and biological glue in patients with high risk of bleeding in stapled hemorrhoidopexy. Arq. Bras. Cir. Dig., 30 (2), 118-121.

Popov, V., Yonkov, A., Arabadzhieva, E., Zhivkov, E., Bonev, S., Bulanov, D., Tasev, V., Korukov, G., Simonova, L., Kandilarov, N., Taseva, A., Dimitrova, V. (2019). Doppler-guided transanal hemorrhoidal dearterilization versus conventional hemorrhoidectomy for treatment of hemorrhoids - early and long-term postoperative results. BMC Surgery., 19 (1), 4.

Porrett, L. J., Porrett, J. K., Ho, Y. H. (2015). Documented complications of staple hemorrhoidopexy: A systematic review. Int. Surg., 100 (1), 44-57.

Rakinic, J. (2018). Benign anorectal surgery: Management. Adv. Surg., 52 (1), 179-204.

Ray-Offor, E., Elenwo, S. N. (2015). Endoscopic evaluation of upper and lower gastro-intestinal bleeding. Nigerian J. Surg., 21 (2), 106-110.

Ray-Offor, E., Amadi, S. (2019). Hemorrhoidal disease: Predilection sites, pattern of presentation, and treatment. Ann. African Med., 18 (1), 12-16.

Ratto, C., Campennì, P., Papeo, F., Donisi, L., Litta, F., Parello, A. (2017). Transanal hemorrhoidal dearterialization (THD) for hemorrhoidal disease: A single-center study on 1000 consecutive cases and a review of the literature. Techn. Coloproctol., 21 (12), 953-962

Rubbini, M., Ascanelli, S. (2019). Classification and guidelines of hemorrhoidal disease: Present and future. World J. Gastrointest. Surg., 11 (3), 117-121

Sardińas, C., Arreaza, D. D., Osorio, H. (2016). Changes in the proportions of types I and III collagen in hemorrhoids: The sliding anal lining theory. $J$. Coloproctol., 36 (3), 124-129.

Schneider, R., Jäger, P., Ommer, A. (2019). Long-term results after stapled hemorrhoidopexy: A 15-year follow-up. World J. Surg., 43, 2536-2543.

Simillis, C., Thoukididou, S. N., Slesser, A. A., Rasheed, S., Tan, E., Tekkis, P. P. (2015). Systematic review and network meta-analysis comparing clinical outcomes and effectiveness of surgical treatments for haemorrhoids. Brit. J. Surg., 102 (13), 1603-1618.

Stoker, J. (2009). Anorectal and pelvic floor anatomy. Best Pract. Res. Clin. Gastroenterol., 23 (4), 463-475.

Sturiale, A., Fabiani, B., Menconi, C., Cafaro, D., Fusco, F., Bellio, G., Schiano di Visconte, M., Naldini, G. (2018). Long term results after stapled hemorrhoidopexy: A survey study with mean follow-up of 12 years. Tech. Coloproctol., 22 (9), 689-696.

Sundel, M. H., Voltaggio, L., Leeds, I. L., Fang, S. H. (2019). Anatomy and histology of the anus. In: Meyer, J., Kachnic, L. (eds). Anal Cancer. Springer, Cham, Chapter 1, pp 1-9.

Talha, A., Bessa, S., Abdel Wahab, M. (2017). Ligasure, Harmonic Scalpel versus conventional diathermy in excisional haemorrhoidectomy: A randomized controlled trial. ANZ J. Surg., 87 (4), 252-256.

Received 26 July 2020

Accepted in the final form 13 November 2020
Tian, H., Huang, J. J., Golzio, C., Gao, X., Hector-Greene, M., Katsanis, N., Blobe, G. C. (2018). Endoglin interacts with VEGFR2 to promote angiogenesis. FASEB J., 32 (6), 2934-2949.

Tradi, F., Mege, D., Louis, G. , Bartoli, J. M., Sielezneff, I., Vidal, V. (2019). Emborrhoid: Rectal arteries embolization for hemorrhoid treatment. Presse medicale, 48 (4), 454-459.

Trenti, L., Biondo, S., Galvez, A., Bravo, A., Cabrera, J., Kreisler, E. (2018) Distal Doppler-guided transanal hemorrhoidal dearterialization with mucopexy versus conventional hemorrhoidectomy for grade III and IV hemorrhoids: Postoperative morbidity and long-term outcomes. Tech. Coloproctol., 22 (6), 479.

Trenti, L., Biondo, S., Kreisler Moreno, E., Sanchez-Garcia, J. L., Espin-Basany, E., Landaluce-Olavarria, A., Bermejo-Marcos, E., Garcia-Martinez, M. T., Jimenez, D. A., Jimenez, F., Aloinso, A., Manso, M. B., THDLIGA-RCT Study Group (2019). Short-term outcomes of transanal hemorrhoidal dearterialization with mucopexy versus vessel-sealing device hemorrhoidectomy for grade III to IV hemorrhoids: A prospective randomized multicenter trial. Dis. Colon Rectum., 62 (8), 988-996.

Venturini, M., De Nardi, P., Marra, P., Panzeri, M., Brembilla, G., Morelli, F., Melchiorre, F., De Cobelli, F., Del Maschio, A. (2018). Embolization of superior rectal arteries for transfusion dependent haemorrhoidal bleeding in severely cardiopathic patients: a new field of application of the "emborrhoid" technique. Techn. Coloproctol., 22 (6), 453-455.

Wallner, C. (2008). Is the puborectalis muscle part of the levator ani muscle? Dis. Colon Rectum., 51 (7), 1165-1167.

Wang, W. G., Lu, W. Z., Yang, C. M., Yu, K. Q., He, H. B. (2018). Effect of lateral internal sphincterotomy in patients undergoing excisional hemorrhoidectomy. Medicine, 97 (32), e11820.

Wu, Y., Dabhoiwala, N. F., Hagoort, J., Shan, J.-L., Tan, L.-W., Fang, B.-J., Zhang, S.-X., Lamers, W.-H. (2015). 3D topography of the young adult anal sphincter complex reconstructed from undeformed serial anatomical sections. PLoS ONE, 10 (8), e0132226.

Willis, S., Junge, K., Ebrahimi, R., Prescher, A., Schumpelick, V. (2010). Hemorrhoids - a collagen disease? Colorectal Dis., 12, 1249-1253.

Xu, L., Chen, H., Lin, G., Ge, Q. (2015). Ligasure versus Ferguson hemorrhoidectomy in the treatment of hemorrhoids: A meta-analysis of randomized control trials. Surg. Laparosc. Endosc. Percut. Techn., 25 (2), $106-110$.

Xu, L., Chen, H., Gu, Y. (2019). Stapled hemorrhoidectomy versus transanal hemorrhoidal dearterialization in the treatment of hemorrhoids: An updated meta-analysis. Surg. Laparosc. Endosc. Percut. Techn., 29 (2), 75-81.

Yamamoto, M., Ikeda, M., Matsumoto, T., Takemoto, M., Sumimoto, R., Kobayashi, T., Ohdan, H. (2020). Hemorrhoidectomy for elderly patients aged 75 years or more, before and after studies. Ann. Med. Surg., 55, $88-92$.

Yilmaz, Ż., Sücüllü, Ż., Karakaž, D. Ö., Özdemir, Y., Yücel, E., Akin, M. L. (2012). Doppler-guided hemorrhoidal artery ligation: Experience with 2 years follow-up. Amer. Surg., 78 (3), 344-348.

Yilmaz, Ż., Özgür Karakaž, D., Sücüllü, Ż. (2016). Long-term results of hemorrhoidal artery ligation. Amer. Surg., 82 (3), 216-220..

Zakharchenko, A., Kaitoukov, Y., Vinnik, Y., Tradi, F., Sapoval, M., Sielezneeff, I., Galkin, E., Vidal, V ( 2016). Safety and efficacy of superior rectal artery embolization with particles and metallic coils for the treatment of hemorrhoids (Emborrhoid technique). Diagn. Interv. Imaging. , 97 (11), 1079-1084.

Zoulamoglou, M., Kaklamanos, I., Zarokosta, M. Flessas, I., Bonatsos, V., Piperos, T., Theodoropoulos, P., Barla, G., Stathopoulou, I., MariolisSapsakos, T. (2017). The ligament of Parks as a key anatomical structure for safer hemorrhoidectomy: Anatomic study and a simple surgical note. Ann. Med., Surg., 24, 31-33. 


\section{IZPLATİTĀ HEMOROIDĀLĀ SLIMĪBA — CIK DAUDZ PAR TO ZINĀMS?}

Hemoroīdi ir asinsvadu spilveni anālajā kanālā — normālas cilvēka organisma struktūras ar fizioloğisku nozīmi. Hemoroidālā slimība ir tad, ja notiek patoloǵiska to palielināšanās, prolapss un/vai asin̨ošana. Hemoroidālā slimība ir ļoti izplatīta, īpaši attīstītās valstīs ar augstu sociālekonomisko stāvokli. Neraugoties uz pēdējās desmitgades daudzajiem pētījumiem un uzkrātajām zināšanām par hemoroidālās slimības etiolog̣iju un patoğenēzi, līdz galam nav saprotami mehānismi, kas ir atbildīgi par slimības attīstību. Iepriekš proponētie etioloǵiskie faktori šobrīd tiek apstrīēeti un pat apgāzti. Patofizioloǵija noteikti ir multifaktoriāla un ļoti sarežğîta. Šì specifiskā slimība negatīvi ietekmē dzīves kvalitāti. Savukārt lietotā kiirurǵiskā ārstēšana, kas balstīta uz Goligera klasifikāciju, ilgtermiṇā nedod pilnīgu izārstēšanos. Ķirurğ́iskai terapijai ir diezgan daudz komplikāciju un bieži recidīvi. Kas primāri ir nepareizi — piel̦autais, patofizioloğiskais, iespējamais mehānisms, taktikas izvēle, pacientu atlase? Tiek spriests par klasifikācijas un vadlīniju uzlabošanu, kas savukārt palielinātu iespējamību pacientu ārstēt ne tikai simptomātiski, bet arī etioloǵiski, ņemot vērā blakussaslimšanas, vecumu, dzimumu. Kā iepriekš noskaidrots, tam ir nozīmīga loma pareizās taktikas izvēlē. Šis literatūras apskats apkopo pieejamo informāciju par pareizi funkcionējošu anālo kanālu, tā anatomiju, iespējamām hemoroidālās slimības attīstības teorijām un tās patofizioloǵiju, sniegts ieskats šā brīža ārstēšanā. 